\title{
Preliminary Reference and the Hungarian Constitutional Court: A Context of Non-Reference
}

\author{
By Fruzsina Gárdos-Orosz ${ }^{*}$
}

\begin{abstract}
"Participation is not an end in itself; it must promote human rights, welfare and security." ${ }^{1}$
\end{abstract}

\section{A. Introduction: The Context of Non-Reference}

Jiri Zemanek, Professor at Charles University, Prague, asks what conclusions may be drawn from the current state of acceptance of the European Union (EU) law doctrine by the constitutional courts of the new Member States for their performance in the agenda of preliminary rulings. What can they learn from the experience of the old Member States? Should they follow the practice of the Austrian Verfassungsgerichtshof (Constitutional Court), which referred its first question in 1999, four years after its accession, and later repeated it several times? Or should they follow the most active Belgian Cour Constitutionnelle? ${ }^{2}$ Should Hungary follow the practice of the Italian Constitutional Court, Lithuania, France, Spain, or Germany? Having reviewed the case law of the Hungarian Constitutional Court and the scholarly analysis in search of the "missing links", ${ }^{3}$ this study wishes to contribute to the diverse range of ideas concerning European "rule of law" integration and constitutional court contributions to it.

Hungary acceded to the EU in $2004 .^{4}$ At the time of its accession, the goal was clearly to achieve perfect coherence between Hungarian law and EU law. ${ }^{5}$ As a starting point, the Parliament amended the Constitution and added a new Article 2/A. ${ }^{6}$ The jurisprudence of the Constitutional Court that will be elaborated later on in this article was mostly based on this provision.

Article 2/A. of the former Constitution stated that:

By virtue of treaty, the Republic of Hungary, for the purposes of its participation as a Member State in the European Union, may exercise

\footnotetext{
* Research Fellow in Constitutional Law at the Hungarian Academy of Sciences, Center for Social Sciences, Institute for Legal Studies; Associate Professor in Constitutional Law at the National University of Public Service, Budapest. Some sections of this article are based on my previous research, published as Fruzsina Gárdos-Orosz, The Constitutional and statutory framework of the application of EU law in Hungary, 55 ACTA UNIVERSITATIS CAROLINAE JURIDICA 203-234 (2014); Fruzsina Gárdos-Orosz, The Hungarian constitutional court in transition: from actio popularis to constitutional complaint, 53 ACTA JURIDICA HUNGARICA 302-315 (2012); Fruzsina Gárdos-Orosz, Citizen's rights to constitutional adjudication in Hungary, in THE TRANSFORMATION OF THE HUNGARIAN LEGAL SYSTEM 2010-2013 117-131 (Péter Smuk ed., 2013 ).

${ }^{1}$ Decision 145/2010. (VII. 14.) CC of 14 July 2014.

2 Jiri Zedenek, The constitutional courts in the new member states and the uniform application of European law, available at http://www.ecln.net/elements/conferences/book_berlin/zemanek.pdf; Giuseppe Martinico, Preliminary reference and constitutional courts: are you in the mood for dialogue? Tilburg Institute for Comparative and Transnational Law Working Paper (TICOM) 1 (2009).

${ }^{3}$ See Part D-Constitutional Courts and the lack of preliminary reference. The missing link, in this Special Issue.

${ }^{4}$ In this paper, I will use the terms 'Community law' and 'EU law' according to their chronology. I use the term EU law for general assessments as well.

${ }^{5}$ For more information about this, see EURÓPAI KözJOG ÉS POLITIKA [European public law and policy] 775-789 (Tamás Kende \&Tamás Szűcs eds. 2006).

${ }^{6}$ It is disputed whether constitutional amendment was an ultimate necessity for accession. See e.g. László Kecskés, Az EU-Csatlakozás magyar alkotmányjogi problémái [Constitutional law issues of Hungary's accession to the EU], 51 MAGYAR TUDOMÁNY 1081-1082 (2006).
} 
certain constitutional powers jointly with other Member States to the extent necessary in connection with the rights and obligations conferred by the treaties on the foundation of the European Union and the European Communities (hereinafter referred to as the "European Union"); these powers may be exercised independently or through the institutions of the European Union. ${ }^{7}$

The new Fundamental Law, which has been in effect since 1 January 2012, states in Section E paragraph (1) that "Hungary shall contribute to the creation of European unity, in pursuit of the greatest freedom, well-being and security for the peoples of Europe." Paragraph (2) adds that:

[b]y virtue of treaty, Hungary, for the purposes of its participation as a Member State in the European Union, may exercise certain powers granted by the Fundamental Law jointly with other Member States, through the institutions of the European Union, to the extent necessary in connection with the rights and obligations conferred by the founding treaties.

Paragraph (3) states that "[t]he law of the European Union may stipulate a generally binding rule of conduct subject to the conditions set out in paragraph (2)." And paragraph (4) of this Section stipulates that "[t]he authorisation to recognise the binding nature of an international agreement referred to in paragraph (2) shall require a two-thirds majority of the votes of the Members of Parliament." ${ }^{8}$

Initiating a preliminary ruling procedure is a possibility, if not an obligation, for the courts of Member States that is aimed at developing the unified interpretation and enforcement of EU law. Judges are free to decide on whether an autonomous and uniform interpretation by the European Court of Justice (CJEU) is necessary to decide the case. Taking all preliminary references, it is rare that courts question the validity of a piece of legislation; most of the references, rather, ask for the interpretation of EU law. ${ }^{9}$ In Hungary, of the 77 preliminary references up until 2013, only 15 were initiated by the Curia (the Supreme Court), more than 4/5 were referred by lower courts (from the middle level of the judicial hierarchy), and no references were made by the Constitutional Court. ${ }^{10}$ But can the Hungarian Constitutional Court be considered at all a court of referral under Article 267 of the Treaty on the Functioning of the European Union (TFEU)? If yes, is it to be considered a court of last instance? Can the Hungarian Constitutional Court be in a situation in which the need to apply and thus interpret EU law emerges and becomes relevant for the purpose of deciding the case? If yes, what are these cases?

In this article, I will describe how the Constitutional Court, by interpreting the Constitution and the Fundamental Law, has refrained from determining the specific consequences of EU accession for the relationship between the constitution and EU law. I explain that the Constitutional Court neither elaborated comprehensively its views on its proper role in achieving the constitutional aim of contribution to the European rule of law integration. I argue that there was, and there certainly will be case and controversy, when it becomes necessary for the Constitutional Court to take a stand on this matter of principle. When the occasions of decision occur, the institution of the preliminary reference may be of help for the Constitutional Court in finding a cooperative solution that is acceptable both for observing the Hungarian constitutional identity and promoting common constitutional goals as Member States of the Union.

\footnotetext{
${ }^{7}$ See KENDE-SZÜCS (note 6), 769-775 on the interpretation of Article 2/A of the Constitution.

${ }^{8}$ See Decision 22/2012. (V. 11.) CC of 11 May 2012 in connection with this. The Constitutional court, conducting an abstract interpretation procedure, determined what treaties may fall within the scope of Section E of the Fundamental Law.

${ }^{9}$ Of the courts of the Member States joining the Union in 2004, only one reference from Malta in 2012 (C-221/09., AJD Tuna, 2011 E.C.R. I01655) claimed the invalidity of an EU regulation. In this case the CJEU could not identify any points where invalidity could occur. Réka Somssich, Előzetes döntéshozatali eljárások a számok tükrében - a 2004 óta csatlakozott országok bíróságai által kezdeményezett elözetes döntéshozatali eljárások 10 évvel a csatlakozás után, [The practice of referring cases in Member States joining the Union in 2004 in the last 10 years], in A MAGYAR BíRÓSÁGI GYAKORLAT AZ ELÖZETES DÖNTÉSHOZATALI ELUÁRÁSOK KEZDEMÉNYEZÉSÉNEK TÜKRÉBEN 31, 42 (András OsZtovits ed. 2014).

${ }^{10}$ Id., 33. and similarly at the webpage of the Curia (the supreme court of Hungary) available at http://www.l b.hu/sites/default/files/joggyak/az_europai_unio_joganak_alkalmazasa.pdf.
} 
My aims are at once descriptive, analytical, and critical. With regard to Hungarian constitutional adjudication several claims are worth discussing. How should the Hungarian Constitutional Court act in case of a claim of unconstitutionality against a certain piece of EU law (1) or Hungarian law that is based on an EU secondary legislation (2)? Why does it not violate the Fundamental Law if a Hungarian piece of legislation is against EU law (3)? What if a new Treaty provision on the extension of EU competence raises the constitutional issue on the extent of sovereignty transfer (4)? As the editors have taken on the challenge of analyzing the role of the preliminary reference procedure in the caw law of constitutional courts, I will refrain from giving a general overview of all relevant Hungarian Constitutional Court cases on the relationship between Hungarian law and EU law. ${ }^{11}$ I will focus, rather, on how the preliminary reference procedure may or may not play a role in the aforementioned cases.

\section{B. The Constitution and the Fundamental Law as the Starting Point}

The oft-criticized EU clause (Article 2/A.) of the former Constitution ${ }^{12}$ textually did not much help the Constitutional Court in answering constitutional issues raised by petitions, because this clause focused on the criteria of accession rather than on the consequences of it. Although the Constitutional Court theoretically did not limit the scope of its examination under Article 2/A to issues with direct impact on the original transfer of sovereignty, ${ }^{13}$ in effect it took a cautious approach in further interpretation. ${ }^{14}$

Article 6 paragraph (4) of the former Constitution declared that "[t]he Republic of Hungary shall contribute to the creation of European unity, in pursuit of the greatest freedom, well-being and security for the peoples of Europe."

The corresponding provisions of the new Fundamental Law are clearly intended to be of consolidating nature, as beyond some linguistic fine-tuning, only one new rule is added to the previous Constitution version: that EU law may set generally applicable rules of conduct. The fact that the EU may adopt such rules was already recognized, in any case, by ordinary court practice:

Article 2/A paragraph (1) of the Constitution, by limiting the exclusive power of legislation, allows Community law adopted pursuant to the founding treaties of the European Union to grant rights to and impose obligations on persons under the sovereignty of a Member State without a separate legal act of the Member State. ${ }^{15}$

The above-mentioned supplementary sentence of the Fundamental Law therefore expressed an already acknowledged characteristics of EU law at a constitutional level in domestic law. Although the Constitutional Court stated in its decision 22/2012 (V. 8.) CC that it regards the new Section E of the Fundamental Law as almost identical to the provision of the previous constitution, and thus the former case law remained relevant

\footnotetext{
${ }^{11}$ For the latest analyses of all relevant decisions of the Hungarian Constitutional Court in English, see Flora Fazekas, EU law and Hungarian Constitutional Court, in EUROPEAN UNION LAW IN HUNGARY: INSTITUTIONS, PROCESSES AND THE LAW 32-73 (Márton Varju \& Ernő Várnay eds., 2014). I will on many occasions use these short analyses in chapter $B$ to highlight the essence of relevant jurisprudence.

${ }^{12}$ For a summary, see IMRE VÖRÖS, CSOPORTKÉP LAOKOONNAL: A MAGYAR JOG ÉS AZ ALKOTMÁNYBíRÓSÁG VÍVÓDÁSA AZ EURÓPAI JOGGAL [LaOCOON GROUP Photo: The Hungarian Law and Constitutional Adjudication in the Light of European Law] 95-111 (2012).

${ }^{13}$ Prior to the accession the Constitutional Court analyzed the possibility of limiting sovereignty in the following decisions: Decision 36/1999 (XI.26.) AB of 26 November 1999; Decision 5/2011 (II. 28.) CC of 28 January 2011; Decision 1154/B/1995 AB of 13 February 2001; Decision 30/1998 (VI. 25.) AB of 25 June 1998.

14 András Sajó, Learning Co-operative Constitutionalism the Hard Way: the Hungarian Constitutional Court Shying Away from EU Supremacy, 3 ZEITSCHRIFT FÜR STAATS- UND EUROPAWISSENSCHAFTEN 351-370 (2004) and Renáta Uitz, EU Law and the Hungarian Constitutional Court: Lessons of the First Post-accession Encounter, in Après ENLARgEMENT. LegAL ANd Political ResPonses IN CENTRAL AND EASTERN EUROPE, 4163. (WojczekSadurski et al. eds. 2006) In a large number of countries whose relevant constitutional rules are similar, constitutional courts adopted decisions discussing these issues much more exhaustively, e.g. Germany, Italy, Spain, or the Czech Republic. A comparative analysis is given by FLÓRA FAZEKAS, A MAGYAR ALKOTMÁNYBíRÓSÁG VISZONYA A KÖZÖSSÉGI JOG ELSÖBBSÉGÉHEZ EGYES TAGÁLLAMI ALKOTMÁNYBÍRÓSÁGI FELFOGÁSOK TÜKRÉBEN [The approach of the Hungarian Constitutional Court to the supremacy of Community law compared to the various approaches of other Member States' constitutional courts] Doctoral dissertation 175-181 (2009) available at http://jog.unideb.hu/media/documents/doktori_nyilvanosvita/fazekas-ertekezes.pdf.

${ }^{15}$ Supreme Court, Mfv.II.10.921/2005, BH+ 2006.422. Translated by the author.
} 
after $2012^{16}$, it is open to debate whether the Constitutional Court may still reinterpret in future jurisprudence its competences with regard to the application of EU law and harmonization issues referring to the new Fundamental Law.

According to the official reasoning of Section E of the Fundamental Law, the EU has an independent legal system established by international treaties, and under EU law it is possible to define rights and obligations directly for persons and entities, and some rules are directly applicable in the territory of the Member States. As Hungary's EU membership has a significant impact on the order and framework of the exercise of public power in Hungary, and as EU law very much determines the rights and obligations of Hungarian persons and legal entities, it is necessary for the Fundamental Law to provide a specific authorisation for exercising powers within the framework of the EU (under organizing principles affecting the entire Fundamental Law). This rule allows Hungary to exercise some of its powers through the institutions of the EU as a Member State. The relevant specific powers must be identified by an international treaty, but the extent of the exercise of powers through the institutions of the EU may not exceed the extent necessary with regard to the international treaty, and may not involve more powers than those of the Hungarian state under the Fundamental Law. ${ }^{17}$

\section{The Constitutional Court as a Court of Referral}

Referring questions for a preliminary ruling cautiously might not have been in the center of scholarly debates prior to 2012, because it was not clear either from the regulation and the case law of the Constitutional Court or from the interpretation of the CJEU if the Hungarian Constitutional Court could at all, at that time, be considered a court or tribunal within the meaning of Article 267 TFEU. ${ }^{18}$ However, the Hungarian Fundamental Law has, in Article 24, significantly modified the competences of the Constitutional Court. ${ }^{19}$ I argue that having regard to its new competences, the Court qualifies as a court of referral under Article 267 TFEU.

Among several changes, the new Fundamental Law introduced three types of constitutional complaint and abolished the former actio popularis. The lively system of actio popularis had entailed the possibility that anyone could turn to the Constitutional Court claiming that a law, legal provision, or a regulation was contrary to a constitutional provision. The petitioner could also request the annulment of that piece of law in this abstract ex post facto review procedure. A constitutional complaint under the former jurisdiction was to be lodged only in the case of a violation of rights caused by the application of an unconstitutional norm.

The aims of the new constitutional complaint mechanisms with the introduction of the German type constitutional complaint is to review not only the constitutionality of a norm applied in a given court case but also to protect against all violations of rights caused by ordinary court decisions. Furthermore, the new complaint system claims to provide individual remedy against unconstitutional law in cases where no other judicial remedy is available.

A new cardinal act governs the Constitutional Court. ${ }^{20}$ Under the new legislation, the primary competence of the Constitutional Court has shifted from the ex-post facto abstract review of laws to the adjudication of constitutional complaints, granting remedies in concrete cases when fundamental rights of individuals or legal entities are violated. ${ }^{21}$ Under the new regulation, petitioners can highlight whether, in a particular case, the application or non-application of EU law, or the incorrect interpretation of EU law, has caused the violation of their constitutional rights. They may further claim that the EU law applied in their case violates their constitutional rights. It is also possible to argue that a Hungarian piece of legislation founded on EU law (e.g., implementing a directive) violates their constitutional rights. The petitioner may claim that the CJEU is the court of last instance in her case therefore her right to effective remedy is violated by the decision of the nonreferring domestic court.

\footnotetext{
${ }^{16} 22 / 2012$ (V. 8.) CC decision of the 8 May 2012 [42]-[46].

${ }^{17}$ Translated by the author.

${ }^{18}$ FAZEKAS (note 14.), 75.

${ }^{19}$ For the elevated importance of the competence of constitutional courts to refer a case to the CJEU see MARTINICO (note 3), 4-6.

${ }^{20}$ Act CLI of 2011 on the Constitutional Court.

${ }^{21}$ Available at www.mkab.hu/statisztika/2014.
} 
As similar questions might be addressed to the Hungarian Constitutional Court after the new Fundamental Law has entered into force, the Court has definitely diminished chance to avoid situations where considering the referral is unavoidable. On the other side, taking into account the new competence of the Constitutional Court, the CJEU, following its case law, could hardly refuse the acknowledgment of the Constitutional Court as court of referral.

\section{The Basic Findings of the Constitutional Court Decisions Regarding its Task in EU related Constitutional Matters}

\section{Implemented Secondary Legislation and the Role of the Constitutional Court}

Following the accession, Decision $17 / 2004$ (V. 24.) CC $^{22}$ was the first occasion when the Constitutional Court had the opportunity to elaborate on how and to what extent it is possible to review the constitutionality of a norm based on EU secondary legislation, namely on a directive. When regulating agricultural surplus stocks a contradiction arose between the Constitution and the Hungarian legislation implementing the EU Commission Regulation. The Constitutional Court conducted a standard ex post facto review of constitutionality and did not take into consideration that the Hungarian legislative measure was partly based on obligatory standards imposed by the Commission Regulation. The review procedure against the Act of 2004 on agricultural surplus stocks was initiated by the President of the Republic. The domestic act ordered that the owners of agricultural surplus stocks had to pay a certain fee if they had an impermissible quantity of products on the date of the accession. Because, due to several amendments, the exact content of the EU requirement was unclear up until a few months before Hungary's accession, the lack of due time for preparation of the targeted owners was partly caused by the Commission Regulation itself.

One of the claims of the President was that the Hungarian law had a retroactive effect that violated the principle of legal certainty. The Constitutional Court in this case, however, did not take into consideration the relevant Commission Regulation and skipped the problem of the relation between the two legal regimes and its role in handling conflicts. The Court noted that the relevant rules of EU law became mandatory with the date of the accession, but claimed that the petitioner required the examination of the Hungarian legislation. In the light of this observation, the Court conducted the standard review and declared several dispositions of the Hungarian regulation to be unconstitutional.

This decision became a precedent for further cases in which the Hungarian legislation transposed EU law. This tendency in the practice of the Constitutional Court might be called the indirect constitutional review of Commission Regulations, as in cases of unconstitutionality the EU law in fact does not apply in Hungary. ${ }^{23} \mathrm{Had}$ the Constitutional Court acknowledged that the Hungarian law to be judged was related to EU law, it should have considered supremacy and the relevant CJEU case law, as well as the question of whether it should turn to the CJEU for a preliminary ruling. This, however, would have led to applying special procedures and special assessments of what constitutionality as such is in a case of a piece of Hungarian legislation based on EU law. At the time of the decision, the Constitutional Court was certainly not prepared to bring a determined decision concerning the constitutional implications of EU membership in this regard. ${ }^{24}$

It was only in 2008, four years after the accession, that reflections on the role of the CJEU first appeared in the case law of the Constitutional Court. ${ }^{25}$ The first decision dealt with the division of competences between the

\footnotetext{
${ }^{22}$ Decision 17/2004 (V. 24.) CC of 24 May 2004.

${ }^{23}$ FAZEKAS (note 11), 53.

${ }^{24}$ Id., 53.

${ }^{25}$ See the case law in more detail in Marton Varju \& Flora Fazekas, The reception of European Union Law in Hungary: The constitutional court and the Hungarian Judiciary, 48 COMMON MARKET LAW REVIEW 1945-1984 (2011). A good counter-example for the standpoint of the Hungarian Constitutional Court is of the Austrian Constitutional Court. The 2012 decision of the Austrian Constitutional Court is available in English http://www.vfgh.gv.at/cms/vfghsite/attachments/9/6/0/CH0006/CMS1353421369433/grundrechtecharta_eng lish u466-11.pdf. - need full citation of this case
} 
Constitutional Court and the CJEU. ${ }^{26}$ The petitioner argued that the obligation that a referring Hungarian court has to notify the minister of justice as well when referring the question to the CJEU breached the Constitution's Europe-clause, because it was inconsistent with ex Article 234 EC treaty (now Article 267 TFEU). The Hungarian Constitutional Court denied its competence to rule on the matter, and continued that "according to the rules of the Community, a decision on the compatibility of the domestic act under review with Community law falls within the competence of EU institutions and as the last instance the European Court of Justice" ${ }^{27}$ The Court referred to the infringement procedure and the preliminary ruling procedure and acknowledged the competence of the European Commission and the CJEU, even in matters of possible conflict between the two legal orders, the non-conformity of Hungarian law with EU law.

Controversially enough, the Constitutional Court mentioned in the same lines that EU law (i.e., ex Article 234 EC Treaty and the relevant case law of the CJEU) leaves the definition of the relevant domestic procedural rules on preliminary references with the Member States, with the reservation that domestic rules cannot exclude the possibility of preliminary reference. ${ }^{28}$ After these considerations, the Court however surprisingly concluded within its own competence that the Hungarian procedural rules on preliminary references were not contrary to EU law in its view. ${ }^{29}$

The application of the doctrine of acte claire was first raised in the case on the agricultural CAP Single Payment Scheme in a dissenting opinion. The procedure in 2010 was also initiated by the President of the Republic, who claimed that the Hungarian Act on Single Payment Scheme for Direct Support Payments under the Common Agricultural Policy (CAP) was unconstitutional. The President of the Republic claimed that the domestic act did not guarantee an adequate period of preparation. Agricultural land owners who had leased their land evidently could not take into consideration the new regulation on the support of certain agricultural activities and domestic lands.

In its Decision 142/2010 (VII. 12.) CC ${ }^{30}$, just as in the case on agricultural surplus stocks, the Constitutional Court argued that the review may concentrate only on the domestic piece of legislation. This interpretation allowed the Constitutional Court to consider the petition of the President of the Republic on its merits. The Court applied again a standard review of constitutionality; it annulled the relevant provisions of the domestic act. The majority opinion of the Constitutional Court did not assess the constitutionality of the contested EU Regulation, openly did not interpret it, and therefore did not discuss the benefits of a preliminary ruling. The Constitutional Court furthermore did not reflect to the jurisprudence of other member states and the ECJ itself finding the examined piece of legislation unambiguous. ${ }^{31}$

The dissenting opinion, however, argued that the majority ruling implicitly engaged in the interpretation of the relevant EU Regulation. It held that it was unacceptable that the Court had failed to consider if it was necessary to ask for a preliminary ruling concerning the interpretation of the Regulation. Logically, as the dissenting opinion emphasized, the Constitutional Court is not capable to judge the margin of appreciation of the Hungarian legislator with regard to the interpretation and due implementation of the Regulation, if does not engage in the interpretation of the Regulation. The dissenting opinion argued that the Court implicitly indeed recognized the acte clair principle in this case, because otherwise it had been its duty to ask for the preliminary ruling of the CJEU. ${ }^{32}$

\footnotetext{
${ }^{26}$ Decision 61/B/2005 CC of 29 September 2008. For the critical analysis of the decision and other relevant decisions see MÁRTADEzső \& ATTILAVINCZE, MAGYAR ALKOTMÁNYOSSÁG AZ EURÓPAI INTEGRÁCIÓBAN [Constitutionality in Hungary within the framework of European integration (2012)].

${ }^{27}$ Repeated by the Decision 281/B/2007 CC of 6 April 2009 and Decision 770/B/2005 CC of 1 September 2009.

${ }^{28}$ The Court referred to Case C-166/73, Rheinmühlen, 197] E.C.R. 33.

${ }^{29}$ See the critical analyses of this case and of other relevant case law in detail in FAZEKAS (note 12) 32- 73.

${ }^{30}$ Decision 142/2010 (7.12.) CC of 12 July 2010.

${ }^{31}$ FAZEKAS (note 14), 75.

${ }^{32}$ Dissenting opinion of Judge Laszló Kiss, I Chapter.
} 
In 2008, the EUIN Agreement decision ${ }^{33}$ interpreted EU law without referring either to clear frameworks of interpretation and the position of EU law or to the task of the Constitutional Court related to EU law. The Agreement between the EU, Iceland, and Norway on extending the scope of application of the surrender procedure according to the European Arrest Warrant (the so-called EUIN Agreement) was brought before the Court by the President of the Republic. He claimed that the exemption made by the Agreement was incompatible with the principle of nullum crimen sine lege (Article 57(4)). The Hungarian Constitutional Court stated that EU rules on the expedited preliminary ruling procedure guarantee that the court that is entitled to issue and receive a European Arrest Warrant obtains authentic interpretation of the European Arrest Warrant Framework Decision within a reasonable time from the CJEU. It follows from the words of the Constitutional Court that it is a constitutional obligation of ordinary courts that they turn to the CJEU if a dispute concerning the interpretation and application, and potentially the validity, of EU law is placed before them. Furthermore, they are bound by the interpretation of the CJEU. ${ }^{34}$ But what about the Constitutional Court itself?

The Hungarian Constitutional Court, when deciding the case, did not take into consideration the fact that the CJEU had declared the European Arrest Warrant Framework Decision compatible with the principle of nullum crimen sine lege. It emphasized, furthermore, that its decision did not affect the EUIN Agreement itself. However, as the EUIN Agreement is strictly linked to the European Arrest Warrant Framework Decision, the decision suggests that there are constitutional rules in domestic law that cannot be violated by the EU when legislating or concluding international agreements. ${ }^{35}$

Decision 744/B/2004 ${ }^{36}$ was about the 2004 Act on Firearms and Ammunition based on the 1991 EU Directive on the control of the acquisition and possession of weapons. The Hungarian Constitutional Court examined the domestic act in an ex post facto review procedure and found that it was constitutional as it was proportionate with the aims of the domestic regulation. Although the Court again did not deal with the original EU Directive, it implicitly suggested that the aims and means of the EU regulation were in harmony with the protection provided by the Hungarian Constitution.

In sum, in cases where the review of constitutionality aimed at examining the Hungarian implementing legislation, the Constitutional Court refrained from taking into consideration the influencing nature of EU legislation. In the course of the standard review of constitutionality, the Constitutional Court with more or less intensity noted the underlying EU legislation, but this did not determine the decision of the Court about the constitutionality of the examined Hungarian law. ${ }^{37}$ The Court did not consider asking for a preliminary ruling, because the sole discussion of the relevant EU secondary law did not influence the decision, meaning that there was no overwhelming need to have an autonomous interpretation of the original EU norm. However, this justification, as I will discuss in part $C$, is not quite convincing if we take into account the fact that the Constitutional Court in many cases should have separated the essential and mandatory content of EU law and other parts of the domestic legislation where domestic legislative organs had a margin of appreciation in implementation.

II. The Constitutional review of EU Law (Especially Secondary Law with Direct Effect) and the Exclusion of the Role of the Constitutional Court

Regarding the lack of competence to review the constitutionality of EU law, the Constitutional Court formulated its strong position quite early on. In the Lisbon decision 143/2010 (VII. 4.) AB, that will be analyzed in more detail below, the Court acknowledged that the Act on the Constitutional Court does not regulate its

\footnotetext{
${ }^{33}$ Decision 32/2008 (III.12.) CC of 11 March 2008.

${ }^{34}$ See the analyses of the decision: Péter Kovács, A la recherche du bon chemin... - ou l'affaire du mandat d'arrêt européen devant la Cour constitutionnelle, in LA FRANCE, L'EUROPE ET LE MONDE, 363-379. (Jean-Denis Mouton ed., 2008).

${ }^{35}$ FAZEKAS (note 11), 56.

${ }^{36}$ Decision 744/B/2004CC of 1 February 2005.

${ }^{37}$ A late exception could be Decision 32/2012 (VII. 4.) CC of 4 July 2012 on the constitutionality of student contracts where the Constitutional Court made efforts to reach a consistent interpretation of EU law and domestic measures.
} 
competences relative to EU law. As I will describe in part III, an exception is the a priori review of EU Founding Treaties and their amendments which can fall under review through the promulgating act. The Constitutional Court in line with the interpretation of the CJEU holds that the CJEU has exclusive competence to decide about secondary legislation.

Interestingly, the Constitutional Court has never developed arguments concerning possible exceptions that may authorize the review in case of potentially ultra vires EU legislation or EU law possibly infringing certain fundamental constitutional provisions. ${ }^{38}$ The only reference to the constitutional boundaries of EU law is found in the Lisbon Decision. It holds that European integration cannot result in the breach of the principles of democracy, a state based on the rule of law, and popular democracy.

The Constitutional Court never went further than this, although the transfer of competence (Section $E$ paragraph 2) is to be interpreted as a domestic constitutional limitation on the law-making powers of the EU. Section E paragraph 3 of the Fundamental Law declares that EU law may stipulate generally binding rules of conduct that are subjected to the conditions set out in paragraph (2). The Constitutional Court has never claimed so far the competence to review if a secondary EU legislation violates Treaty provisions and is therefore contrary to Section E)of the Fundamental Law. In this case preliminary reference on invalidity would be unavoidable.

\section{Treaties and the Role of the Constitutional Court}

Decision $143 / 2010$ (VII. 14.) CC $^{39}$ offers the most comprehensive interpretation of the extent of the transfer of sovereignty and the role of the Constitutional Court in reviewing the constitutionality of the division of competence between Hungary and the EU. The petitioner requested the a posteriori examination of the unconstitutionality and also the annulment of the Act of Parliament implementing the Treaty of Lisbon. In the petitioner's opinion, certain rules of the Treaty of Lisbon restricted Hungary's sovereignty to an extent that, if their binding nature was recognized, the Republic of Hungary "would no longer qualify as an independent state governed under the rule of law."

The Constitutional Court conducted a substantive constitutionality review, the final conclusion of which was that the Act of Parliament promulgating the Treaty of Lisbon was not unconstitutional because the constitutions of Member States could still exercise control over the operation of the EU. The principles of subsidiarity and proportionality would remain valid, and they ensure that the parliaments of Member States would still have the power to review draft legislation. Also, Member States would have the right to initiate an action for annulment, citizens could turn to the institutions of the EU through a Citizens' Initiative, and the Charter of Fundamental Rights, which safeguards basic rights, now has the same value as the treaties. ${ }^{40}$

Undoubtedly, the Constitutional Court made efforts to establish a constitutionality standard, but similarly to Germany's ruling on the Treaty of Lisbon, it could have discussed in much more detail whether the Hungarian state indeed confers, under Article 2/A of the Constitution, the power on the EU to establish new EU competences. $^{41}$

The Constitutional Court declared that "if the Constitutional Court found an Act of Parliament implementing such a treaty (i.e. a treaty amending the founding and amending treaties of the European Union) unconstitutional, the decision of the Constitutional Court establishing unconstitutionality may not have an effect on the Republic of Hungary's duties as a Member State of the European Union. The result of the Constitutional Court's decision is that the legislator must create a situation in which the Republic of Hungary is able to fully comply with its duties under EU law without violating the Constitution“".

\footnotetext{
${ }^{38}$ FAZEKAS (note 11), 59.

${ }^{39} 143 / 2010$ (VII. 14.) AB of 14 July 2010.

${ }^{40}$ Section IV.2.5 of the Decision.

${ }^{41}$ László Blutman, Reagálás az első szám vitainditójára - A Magyar Lisszabon-határozat: Befejezetlen szimfónia Luxemburgi hangnemben [Reaction to the first issue's article that sparked a debate - the Hungarian Lisbon ruling: Unfinished symphony with a Luxembourgish tone]. 2 ALKOTMÁNYBíRóSÁGI SZEMLE, 90,98,99 (2010).
} 
Although the Constitutional Court found that the final interpretation of the Founding Treaties and secondary legislation belonged to the competence of the CJEU, this did not prevent the Hungarian Constitutional Court from referring to certain provisions of the Lisbon Treaty connected to the case without providing or requiring their autonomous interpretation. In the Lisbon decision, this approach led to a rather superficial overview of the Lisbon Treaty's provisions on withdrawal from the EU, on the subsidiarity control mechanism, on the European Citizens' Initiative or on the Charter of Fundamental Rights. The Court did not consider the duty to refer these contested questions to the CJEU for autonomous interpretation first ${ }^{42}$ before applying them as reasoning to the constitutional decision. ${ }^{43}$

In Decision 22/2012 (V.8.) CC, the Constitutional Court held, in a procedure aimed at the abstract interpretation of Section E paragraph (2) and (4) of the Fundamental Law, that:

the votes of two-thirds of the Members of the Parliament is required for the consent to be bound by an international treaty aimed at modifying or amending the rights and obligations originating from the founding treaties, provided that the treaty is aimed at jointly exercising further competences originating from the Fundamental Law. An international treaty can be, in particular, regarded as such, if Hungary is a party to it as the Member State of the European Union together with other Member States, and the treaty regulates subjects contained in the founding treaties, or it is aimed at implementing or supervising the founding treaties. The votes of two-thirds of the Members of the Parliament are not required for the consent to be bound by an international treaty, if the treaty would not result in exercising, jointly with the institutions of the European Union or with other member states, new competences originating from the Fundamental Law. ${ }^{44}$

Although in this procedure related to the Treaty on Stability, Coordination and Governance in the Economic and Monetary Union the dilemma of asking for a preliminary ruling was not (and could not be) raised, the decision reinforces the former standpoint of the Constitutional Court, namely that it does not hold it necessary to engage in constrained interpretation, in interaction with the $\mathrm{CJ}-\mathrm{e}-\mathrm{u}$ in these matters.

\section{Collision of EU law and Hungarian Law at Non-Constitutional Level and Consistent Interpretation - The Role of the Constitutional Court}

The final group of cases in my assessment concerns the review of the constitutionality of certain Hungarian acts that are claimed to be incompatible with EU law. The Constitutional Court declared that it does not have the competence to review whether Hungarian sub-constitutional legal acts are incompatible with EU law. Nor does the Constitutional Court check the adequacy of the transposition of EU secondary legislation. The Constitutional Court argues that Article 2/A of the Constitution and consequently Section E of the Fundamental Law does not require that the Hungarian legislation be in full conformity with EU law. This is why the Constitutional Court, in applying the constitution, cannot say that a Hungarian legal instrument that is contradictory to compulsory EU legislation is unconstitutional. ${ }^{45}$

\footnotetext{
${ }^{42}$ It is worth mentioning that no other constitutional court asked for preliminary ruling in the case of assessing the constitutionality of the Lisbon Treaty.

${ }^{43}$ The English language press release on the Lisbon Decision contains a reference to the fact that the Court 'used the theory of acte clair, but the decision itself did not contain this reference. - need paragraph number of this. Available at http://alkotmanybirosag.hu/letoltesek/en_0143_2010.pdf.

44 The official translation is found at the homepage of the Constitutional Court, available at http://www.mkab.hu/letoltesek/en_0022_2012.pdf.

${ }^{45}$ Decision 66/2006 (XI. 28.) CC of 28 November 2006; Decision 87/2008 (VI. 16.) CC of 16 June 2008. Similarly, Decision 61/B/2005 of 29 September 2008; Decision 770/B/2005 CC of 1 September 2009; Decision 29/2011 (IV.5.)CC of 5 April 2011; Decision 1053/E/2005 CC of 16 June 2006; Decision 72/2006 (XII.16.) CC of 15 Dec. 2006. Cases collected by FAZEKAS (note 12), 64.
} 
However, a concurring opinion attached to Decision 72/2006 (XII. 15.) CC claimed that the Court should have determined the constitutional requirements that must be enforced even in those cases where, as a general rule, the Constitutional Court does not have competence. The concurring judge suggested that when the violation of constitutional rights is at stake, the Court should review whether the legislator violated an obligation flowing from EU law. The non-compliance of Hungarian legislation with EU law in other cases cannot belong to the competence of the Constitutional Court, because the analyses of non-compliance in all cases necessitate the interpretation of EU law which falls within the competence of the CJEU. This argument, laid out in the concurring opinion, has never appeared in a majority decision of the Constitutional Court.

The fact that the Constitutional Court's jurisprudence is strict about refusing this competence, relying on the textual interpretation of the constitution, leads to uncertainties in some court cases. These concern the applicable law and, in some cases, might harm parties when the EU law is more favorable for them, or when the non-compliance causes a violation of their rights such as the right to non-discrimination. ${ }^{46}$

A decision of 2008 seemed to represent a slightly different stance regarding the possibility of transforming the question of non-conformity into a constitutional issue. The petitioner required the constitutional review of certain rules of the act on the preservation of nature. The provisions were based on the Convention on International Trade in Endangered Species of Wild Fauna and Flora Agreement (CITES) and an EU Regulation. The act regulated the keeping of birds taken from the wild and those born in captivity and used for falconry. The petitioners claimed that the uniform regulation of these activities breached the principle of equal treatment and the right to property. ${ }^{47}$ Although the first question to assess was the constitutionality of the implementing Hungarian legislation, after deciding that the act was in conformity with the Constitution, the Constitutional Court examined the compatibility of the Hungarian provisions with EU law too. It declared the domestic measures to be in conformity with EU law.

The conduct of the Constitutional Court here does not amount to a radical change in the jurisprudence, as it did not say that in case of non-conformity of the Hungarian act with EU law a breach of the Constitution could be established. Rather, the Court turned to EU law, to the 1979 Directive, to find the meaning of 'falconry' in the Hungarian act and then to decide about constitutionality. The Court in this case ruled on the constitutionality of a Hungarian norm, relying in its interpretation on EU law. However, the Constitutional Court did not have problems with the interpretation of EU law and thus did not consider turning to the CJEU for a preliminary ruling.

Decision 32/2012 (VII. 3.) CC on the constitutionality of student contracts is also worthy of mention. The petitioner argued, among other claims, that the Hungarian legislation was incompatible with EU law. This argument was not rejected automatically by the Constitutional Court, on the basis that the Court does not deal with the pure contradiction of Hungarian law and the EU law. Rather, the Court referred to the obligation of the consistent interpretation with EU law and examined the contradictions. ${ }^{48}$

In sum, whilst the jurisprudence of the Constitutional Court on this issue is quite strict on the surface, it is not always consistent. The approach may change as well, because the composition of the Constitutional Court has changed significantly over the years. ${ }^{49}$ If the Constitutional Court engages in harmonious (consistent) interpretation, asking for preliminary rulings will be unavoidable in certain cases. It will become necessary to distinguish and identify the cases of acte clair and acte eclairé and to recognize the cases in which it is necessary to ask the CJEU for a preliminary ruling.

\section{In Search of the "Missing Link"}

\footnotetext{
${ }^{46}$ FAZEKAS (note 14), 65.

${ }^{47}$ Decision 485/E/2003 CC of 13 October 2008.

${ }^{48}$ FAZEKAS (note 11), 69.

${ }^{49}$ I refer not only to the significant change in the composition of the Court (every new member of the Court can be linked to the governing FIDESZ party due to the election procedure) but also to the fact that the number of the members of the Constitutional Court was increased from 11 to 15 .
} 


\section{Theoretical Considerations About the Possible Task of the Constitutional Court in Harmonising EU Law and Domestic Law While Protecting the National Constitution}

In the following part of the article, I will consider the critique presented in the Hungarian legal literature concerning the constitutional relationship of the two legal regimes and the task of the Constitutional Court in determining this without cooperating with the CJEU. Hungarian authors have often dealt, in particular, with the interpretation of the transfer of sovereignty.

As indicated above, we know very little from the jurisprudence of the Hungarian Constitutional Court about the assessment of the accession clause of the Constitution and the almost identical provision of the Fundamental Law, and thus about the extent of the transfer of competence and finally, in abstracto, about the task of the Constitutional Court regarding the clarification of the relationship between Hungarian law and EU law. According to Sadurski, an important foreign analyst of Hungarian legal practice, the Hungarian Constitutional Court, in a manner similar to the German Federal Constitutional Court, appears to be adopting a stand of protecting the primacy of the national Constitution. ${ }^{50}$ The paradox is that the Constitutional Courts of Member States have developed their position on this on the basis of an assumption that Member States are sovereign while the EU acquires sovereignty for itself through its sui generis legal system.

The accession clause in Hungary allows a separate body of law to enter Hungarian law. Although the so-called EU clause in the Fundamental Law allows the "joint exercising of powers", which emphasizes the limits on the transfer of powers and, at the same time, stresses the normative nature of cooperation, the "influx" of EU law is controversial. Although S ection E of the Fundamental Law should grant precedence of application to EU law in the case of a conflict between the legal regimes, the case law of the Constitutional Court remains controversial. $^{51}$

For the purposes of doctrinal clarity in Hungarian constitutional law, it would be useful to develop a coresovereignty test that defines the Fundamental Law's inviolable essential content that is to be preserved from the legal effects of EU membership. ${ }^{52}$ This definition of counter-limits could set the ultimate boundaries of the transfer of sovereignty, and it would also define the relationship between the CJEU and Hungarian Constitutional Court on specific issues. It would also help in the context of deciding when to issue a preliminary reference. and when to decide solely at a domestic level.

It is well known that in EU law, the division of powers between Member States and the EU is not regulated by a single rule but instead by countless rules scattered in the acquis determining what the EU institutions are authorized to do. The ultimate limits of this competence must, therefore, be fixed in domestic law through interpretation of national constitutions, no matter which national state organ is responsible for the task in question. The EU is authorized to take advantage of loopholes in the founding treaties, ${ }^{53}$ but under EU law it must also respect the constitutional identity of the Member State (Article 4 (2) TFEU). ${ }^{54}$

According to this train of thought, a persistent conflict is that while the basic doctrine of the accession clause of the Fundamental Law states that the state will only yield power to the EU "to the extent necessary", in connection with the rights and obligations conferred by the founding treaties, EU law states that it is up to the CJEU to determine what this 'necessary extent' means, because, to determine this, the objectives of EU law

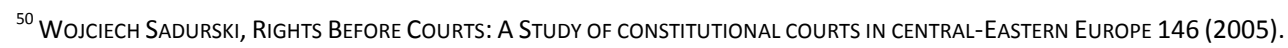

${ }^{51}$ Imre Vörös, Európai jog-magyar jog: konkurencia vagy koegzisztencia? [EU law and Hungarian law: competition or coexistence?] 66 JOGTUDOMÁNYI KÖZLÖNY 373,396-399 (2011).

52 Id.,399.

${ }^{53}$ ANDRÁS JAKAB, A MAGYAR JOGRENDSZER SZERKEZETE [The structure of the Hungarian legal system] 236 (2007).

${ }^{54}$ The new challenge is the application of Art. 4(2) TFEU concerning the respect of the constitutional identity of Member States. See e.g. Giuseppe Martinico, What lies behind Article 4.2 TEU?, in NATIONAL CONSTITUTIONAL IDENTITY AND EUROPEAN INTEGRATION 93-108 (Salz Arnaiz \& C.Alcoberro Livina ed., 2013) The development of this discourse will certainly have an effect related to the role of constitutional courts.
} 
need to be interpreted. ${ }^{55}$ In sum, according to EU law, it could be necessary in certain cases to refer the question on the competence-competence issue to the CJEU; from the point of view of domestic law, however, it falls within the competence of the Member State to define the transfer of competence by the interpretation of the domestic constitution and without asking for a preliminary ruling.

The obligation of acting jointly, however, might also mean that EU law may not separate itself from the law of Hungary; therefore, according to the principles of democratic legitimation and authorization, the ultimate source of the EU acquis is the Member State's constitution. For these reasons, the Member State's constitution must be relied on regarding regulatory issues that may not be given up to the $\mathrm{EU}$, on the basis of the remaining essential sovereignty.

Following this line of argument, one cannot claim that the Constitutional Court should have issued a question to the CJEU, or should have asked for autonomous interpretation such as in the above-mentioned case about the assessment of the Act on implementing the Lisbon Treaty. One can argue that the Hungarian Constitutional Court reserved for itself the right to decide on the meaning of the Lisbon Treaty and the Charter of Fundamental Rights and the sovereignty transfer necessary to accept it. The Constitutional Court just reaffirmed the position of not interpreting EU Treaties solely with the interpretative tools and context developed in EU law, but using also its proper Hungarian constitutional assessment when it comes to deciding on the possible transfer of sovereignty by the Fundamental Law. This position, however, ignores the fact that EU Treaties, when accepted by the Member States, will be ultimately interpreted by the CJEU, and that secondary norms will be adopted within the framework of the Treaties as interpreted by the CJEU.

Regarding the other main issue here, the review of constitutionality of Hungarian law based on EU law, many authors argue that the Hungarian Constitutional Court could examine whether the disputed Hungarian law actually transposes the content of an EU Directive (in this case, no constitutionality review would be possible) or includes rules when the Directive intentionally allows the legislator of the Member State to determine the regulation. In the latter case, actual review of constitutionality would be allowed, but in addition to tests of fundamental rights or other standard tests of the Hungarian Constitutional Court, the interests of the EU and the objectives of the EU regulation would need to be taken into account. ${ }^{57}$ Following this opinion, in principle it would become possible for the Constitutional Court to find, for example, that the EU level of fundamental rights protection is insufficient, leading it to annul the implementing legislation. However, the method of review may not be the same in these cases concerning the constitutionality/fundamental rights test, because the obligation of cooperation imposed on Member States must be taken into account. This obligation may be fulfilled because of Section E of the Fundamental Law. Cooperation becomes possible either by adopting the French solution (which is that the Constitutional Court only offers remedies if the violation of a fundamental right is exceptionally serious), or by following the German approach (which is of only dealing with cases if it can be established that the protection of fundamental rights under EU law is reduced). ${ }^{58}$ Following this line of argument even further, there are cases in which it is necessary that the Constitutional Court refers the case to the CJEU and asks for the autonomous interpretation of the EU legislation, regarding its purposes, core content, and objectives.

Others argue that even less than this could be supervised by the Hungarian Constitutional Court in the case of Hungarian norms based on EU law. For example, it could intervene only if rules on the limits of the transfer of competence or rules representing the essential provisions of the constitution were violated. ${ }^{59}$

In sum, the Hungarian legal scholarship is quite unanimous in accepting the case law of the Constitutional Court that EU secondary law as such cannot be examined by the Constitutional Court from the point of view of

\footnotetext{
55 JAKAB (note 53), 249.

56 Pál Sonnevend, Alapvető jogaink a csatlakozás után. [Our fundamental rights after the accession] 7 FUNDAMENTUM, 27-37 (2003).

${ }^{57}$ Ernő Várnay, Az Alkotmánybíróság és az Európai Unió joga [The Constitutional Court and the Law of the European Union], 62 JOGTUDOMÁNYI KÖZLÖNY 428, 432 (2007).

${ }^{58}$ Id., 432.

${ }^{59}$ Nóra Chronowski \& Zoltán Nemessányi, Alkotmánybíróság-Európai Bíróság: felületi feszültség [Constitutional Court vs. the European Court of Justice: surface tension],4 EURóPAI JOG 19, 27 (2004).
} 
domestic constitutionality, meaning that the question of preliminary references does not arise in these cases (1). However, when it comes to Treaties (2), or even the review of Hungarian law implementing EU law (3), many authors claim that it would be necessary for the Constitutional Court to identify EU law elements and EU law influence and to refer the question to the CJEU if necessary to discover the autonomous interpretation. Coherent interpretation would also be necessary in order to protect the aims and duties formulated in Section E of the Fundamental Law, and this would not be possible without cooperating with the EU and asking for a preliminary ruling when necessary (4). The context of non-reference is defined by uncertainty, and the missing link here could be a clear doctrine similar to the doctrines developed by some other Member States.

\section{The Reality: The Application of Preliminary Reference by Ordinary Courts}

What must have become clear for ordinary courts on the basis of the relevant decisions of the Constitutional Court is that a Hungarian law violating EU law is not to be considered unconstitutional automatically. The task of resolving any conflict between a Hungarian piece of legislation and EU law will still be reserved for ordinary courts. The task of ensuring uniformity was carried out by the Supreme Court after accession.

Closely connected to constitutional rights or principles, Hungarian courts mostly refer cases to the CJEU in matters of administrative law, though the subject-matters are very divergent. Courts have even also asked for the interpretation of provisions of the Charter of Fundamental Rights, although without any success. ${ }^{60}$ When compared with the other Member States which joined the EU in 2004, the Hungarian courts have been quite active in asking the CJEU for interpretations of EU law. ${ }^{61}$

In Hungary, ordinary courts are responsible for the efficient enforcement of claims made under EU law, the ex officio application of EU law if necessary, the interpretation of national law in conformity with EU law, disregarding national law if it violates law, and requests for preliminary rulings from the CJEU if necessary or obligatory. These duties derive from the "loyalty clause" in Article 4(3) of the Treaty on European Union (TEU) and the CJEU's related case law, the requirement of uniform and efficient application, and the primacy of EU law. ${ }^{62}$ Ordinary courts apply the acquis more or less in line with the set of requirements imposed by the CJEU, which is practically why it is possible that the task of the Constitutional Court is less emphasized in Hungary's everyday legal practice.

\section{Competition or Cooperation? - A Necessarily Ad Interim Conclusion}

In contrast with international law, which is treated uniquely in Hungary, the legislator has not developed special procedures or methods for assessing the constitutionality of Hungarian laws based on EU law or EU law applicable in Hungary. As Section E of the Fundamental Law acknowledges, EU law may set generally applicable rules of conduct in Hungary. Irrespective of whether they are implemented in Hungarian law, they form part of the rules of conduct.

I argued that it is problematic how the Hungarian Constitutional Court differentiates between implemented and non-implemented EU secondary law with regard to the possibility of constitutionality review. As I demonstrated above, the Constitutional Court has, so far, taken quite strongly the position that it does not have the competence to review the constitutionality of EU norms themselves, not even when they are directly applicable in Hungary. However, it struck down Hungarian legislation that was based on EU law without examining whether the Hungarian legislator had any discretion in deciding on the content of the exact provisions or whether it was strictly bound by EU law.

\footnotetext{
${ }^{60}$ Most cases are connected with the effectiveness of the decision-making process and fair procedure and fair treatment from the officer's side. Zsófia Varga, Az alapjogi Charta a magyar bíróságok elött. [the Charter of Fundamental Rights before the Hungarian Courts] 68 JOGTUDOMÁNYI KÖZLÖNY 553-562 (2013)

${ }^{61}$ SoMSSICH (note 9), 31.

${ }^{62}$ FAZEKAS (note 14), 349.
} 
The Constitutional Court, following its previous case law, carries out a standard substantive constitutionality review in cases of petitions aimed at the constitutionality review of Hungarian laws based directly or indirectly on EU law. This might result in an open confrontation of domestic law, domestic institutions, and EU law and EU institutions. (This would also be the case if the Constitutional Court claimed that it had competence to review compulsory rules of conduct imposed by EU legislation directly if they violate the essential principles of the Fundamental Law, the constitutional identity, and established the unconstitutionality of a directly applicable legal instrument.)

I argued that even in the case of acceptable theoretical foundations for such positions in domestic law, without cooperating with the CJEU on matters affecting the application of EU law, the conduct of the national constitutional court might produce different sets of applicable rules or interpretations in Hungary than in other Member States. This obviously violates several EU principles. Why not instead seek cooperative solutions that are acceptable for both the EU and the national constitutional court? The institution of preliminary reference could also be very useful for the sake of preserving national constitutional identify by convincing the CJEU to favor one interpretation to the other. Dialogue in case of conflict might develop solutions favorable for both the Member State and for its Union.

The theoretical possibility that the Hungarian Constitutional Court engages in a dialogue with the CJEU in the near future is not excluded. Having regard to the fact that the text and the context of the new Fundamental Law in Hungary are similar but not identical to the former Constitution regarding the integration clause (Article E) and other relevant provisions, it is possible that in the event of a competent petition, the Constitutional Court would reconsider the position it developed in Decision 22/2012 (V. 8.) AB and reflect on some basic questions of interpretation.

In borderline cases, the preliminary reference procedure gives the opportunity to the CJEU to decide on the interpretation and scope of EU law. In case the CJEU determines which parts of the norm under constitutionality review must be bound strictly by the secondary legislation as interpreted by the CJEU, and what the issues are where the Member States have discretionary powers, the Hungarian Constitutional Court becomes competent to decide on how to rule on the constitutionality of the different provisions of the examined piece of law.

I argued that the Hungarian Constitutional Court, with its new competences and constitutional complaint mechanisms, definitely qualifies as a court of reference under Article 267 TFEU. Two sui generis legal regimes, EU law and the law of a Member State, will have to resolve legal disputes in a coordinated manner, with respect for each other and with regard to common goals and values. 